\title{
Megalocytiviruses in ornamental fish: A review
}

\author{
Che Azarulzaman Che Johan (D) and Sandra Catherine Zainathan (i) \\ Department of Fisheries and Aquaculture, Faculty of Fisheries and Food Science, University Malaysia Terengganu, \\ Terengganu, Malaysia. \\ Corresponding author: Sandra Catherine Zainathan, e-mail: sandra@umt.edu.my \\ Co-author: CACJ: z_azarul@yahoo.com \\ Received: 09-07-2020, Accepted: 19-10-2020, Published online: 30-11-2020
}

doi: www.doi.org/10.14202/vetworld.2020.2565-2577 How to cite this article: Johan CAC, Zainathan SC (2020)

Megalocytiviruses in ornamental fish: A review, Veterinary World, 13(11): 2565-2577.

\begin{abstract}
Iridoviruses, especially megalocytiviruses, are related to severe disease resulting in high economic losses in the aquaculture industry worldwide. The ornamental fish industry has been affected severely due to Megalocytivirus infections. Megalocytivirus is a DNA virus that has three genera; including red sea bream iridovirus, infectious spleen and kidney necrosis virus, and turbot reddish body iridovirus. Megalocytivirus causes non-specific clinical signs in ornamental fish. Cell culture, histology, immunofluorescence test, polymerase chain reaction (PCR) assay, and loop-mediated isothermal amplification assay have been used to diagnose megalocytiviruses. Risk factors such as temperature, transportation (export and import), and life stages of ornamental fish have been reported for the previous cases due to Megalocytivirus infections. In addition, other prevention and control methods also have been practiced in farms to prevent Megalocytivirus outbreaks. This is the first review of megalocytiviruses in ornamental fish since its first detection in 1989. This review discusses the occurrences of Megalocytivirus in ornamental fish, including the history, clinical signs, detection method, risk factors, and prevention measures.
\end{abstract}

Keywords: clinical signs, detection, Megalocytivirus, ornamental fish, risk factors.

\section{Introduction}

Ornamental fish are known to be affected by Megalocytivirus [1-5], which can cause systemic infections in a wide variety of freshwater and marine fish [6], including amphibians [7]. Megalocytivirus is an important genus of fish viruses in the Iridoviridae (the Iridoviruses) family [8]. The Iridoviridae family is divided into five genera, which include Chloriridovirus, Iridovirus, Lymphocystivirus, Megalocytivirus, and Ranavirus. Megalocytivirus is the most recently added genus [9,10]. Megalocytiviruses are large icosahedral DNA viruses measuring 120-200 nm in diameter [11] and have a large single linear dsDNA genome [12]. Megalocytivirus isolates exhibit relatively few genetic differences and have been divided into three major groups based on genetic sequencing data. These groups are represented by infectious spleen and kidney necrosis virus (ISKNV), red sea bream iridovirus (RSIV), and turbot reddish body iridovirus (TRBIV) [13]. The most frequently identified megalocytiviruses are RSIV and ISKNV [14]. Song et al. [15] evaluated 48 Asian and Australian Megalocytivirus isolates with regard to their geographic locations and genetic variations in the major capsid protein (MCP) gene. Based on the results, they developed a phylogenetic tree that divided the 48 isolates into three distinct clusters based on genotype.

Copyright: Johan and Zainathan. Open Access. This article is distributed under the terms of the Creative Commons Attribution 4.0 International License (http://creativecommons.org/licenses/ by/4.0/), which permits unrestricted use, distribution, and reproduction in any medium, provided you give appropriate credit to the original author(s) and the source, provide a link to the Creative Commons license, and indicate if changes were made. The Creative Commons Public Domain Dedication waiver (http:// creativecommons.org/publicdomain/zero/1.0/) applies to the data made available in this article, unless otherwise stated.
One of these clusters (genotype I) is widely distributed among several Asian countries, including 13 isolates from Korea, nine isolates from Japan, one isolate from Thailand, one isolate from China, and one isolate from the South China Sea [15]. In contrast, the other two genotypes have smaller host ranges and are locally distributed [15]. Genotype II megalocytiviruses infect freshwater fishes from Southeast Asia and Australia, whereas genotype III megalocytiviruses primarily infect flatfish in China and Korea [15].

The first outbreak of Megalocytivirus-induced disease was recorded in the Japanese cultured red sea bream (Pagrus major) in 1990 and was designated as RSIV disease [8]. In 2001, the complete genome sequence of ISKNV was determined using the next-generation sequencing technique VIDISCA-454, where sequences of an unknown virus were detected in the serum of diseased fish. The near-complete genome sequence of the virus was determined, which showed a unique genome organization and low levels of identity to known members of the Iridoviridae. Based on the homology of a series of putatively encoded proteins, the virus was identified as a novel member of the Megalocytivirus genus in 2001 [8], and in the following year in Japan, Megalocytivirus was identified in ornamental fish, African lampeye Aplocheilichthys normani, and dwarf gourami Colisa lalia imported from Singapore [16]. Next, in 2005, the identification of genotypes within the species of Megalocytivirus we made [17], and in 2006, genetic vaccines for RSIV were generated from DNA vaccines against RSIV infection in fish using the MCP gene and an open reading frame (ORF) containing a transmembrane domain [18]. 
In 2006, it was understood that global trade of ornamental fish may facilitate the spread of Megalocytivirus and enable the emergence of disease in new host species in distant biogeographic regions [19]. In the same year, an outbreak of iridovirus was reported among various fish species in Taiwan. These megalocytiviruses showed high homology (97\% identity) to RSIV with the presence of unidentical nucleotide sequences [20]. In 2008, a phylogenetic tree revealed three clusters: Genotype I, including nine Japanese isolates, 13 Korean isolates, one Chinese isolates, one Thai isolate, and one South China Sea isolate; genotype II, including five freshwater fish isolates in Southeast Asian countries and Australia; and genotype III, consisting mainly of flatfish isolates in Korea and China. This suggests that viruses belonging to genotype I were widely distributed among various fish species in many Asian countries [15]. Furthermore, in 2009, a detailed study of ISKNV infection in an imported ornamental fish was conducted. Phylogenetic analyses using sequences from a portion of the DNA polymerase, MCP, and ATPase genes of Banggai cardinalfish iridovirus in Pterapogon kauderni with the presence and systemic distribution of enlarged virus-infected cells, demonstrated a close relationship with ISKNV [21].

This review is intended to provide an update on the prevalence of megalocytiviruses, including the history, clinical signs, detection method, risk factors, and prevention measures, which will of interest to aquaculturists that are involved in ornamental fish farming and trading around the world.

\section{History of Diagnosis and Cases of Megalocytivirus Infection in Ornamental Fish}

Many cases have reported on the infection of Megalocytivirus in ornamental fish. In 1989, the presence of numerous virions as large aggregates within many cells in chromide cichlid Etroplus maculatus was revealed. The polyhedral particles measured approximately 180-200 nm and had a round central core [22]. The structure, size, and cytoplasmic assembly of the virion classified it within the Iridoviridae family [22]. In 1990, a juvenile angelfish (Pterophyllum scalare) was bought from a local pet shop in Canada and introduced into a tank that contained matured angelfish from the same shop. The juvenile angelfish was found dead $60 \mathrm{~h}$ after it was transferred into the tank. A histological test found massive necrosis and hemorrhage of the hematopoietic tissue in the kidney and spleen and necrosis of the pancreas [23]. Anderson et al. [24] reported that dwarf gourami, C. lalia imported from Singapore, displayed systemic amoebiasis in intestinal and peritoneal lesions. Electron microscopy observation demonstrated the presence of iridovirus-like virions. A batch of juvenile angelfish $(P$. scalare) bred in the United Kingdom died within 2 days of purchase [25]. The spleen of the two fish was sampled, and the histopathology result showed the presence of numerous virions in large groups in the cell cytoplasm. The structure and size of the virions suggested that they were Iridoviruses, yet that was not confirmed until much later. In 2001, there was an outbreak caused by Iridoviruses in tropical ornamental fish farms in Israel. A systemic viral infection in Trichopodus trichopterus, Trichopodus leerii, and swordtail Xiphophorus hellerii has occurred in endothelial cells that become hypertrophic, and an outbreak of lymphocystis in freshwater angelfish $P$. scalare and gourami was also reported [26].

ISKNV-like viruses, African lampeye iridovirus, and dwarf gourami iridovirus (DGIV) were detected in freshwater African lampeye (A. normani) and dwarf gourami (C. lalia), which were imported into Japan in 2002 [16]. A. normani was cultured in freshwater ponds in Indonesia Island of Sumatra and C. lalia was cultured in freshwater ponds in Malaysia before tropical fish wholesalers from Singapore exported it to Japan. The histology result for A. normani showed many inclusion body-bearing cells (IBCs) and necrotic cells in the pulp from spleen. Meanwhile, the spleen of $C$. lalia displayed many early-stage IBCs, matured IBCs, and necrotic cells in the pulps, and the kidney showed many matured IBCs in the hematopoietic tissue. Gibson-Kueh et al. [27] examined four species of tropical freshwater ornamental fish, including dwarf gourami (C. lalia), pearl gourami (T. leeri), Siamese fighting fish (Betta splendens), and angelfish (P. scalare). The samples were derived from newly dead fish. The histological results showed that all of the affected fish demonstrated basophilic and hypertrophied cells in various organs. Petty and Fraser [28] found iridovirus in freshwater angelfish that showed an enlarged abdomen and abnormal body in a high mortality occurrence at the farm.

In 2005, the International Committee on Taxonomy of Viruses accepted a new genus known as Megalocytivirus under the Iridoviridae family based on the appearance of enlarged cells that were observed on histological examination of infected fish [29]. Many cases of outbreak caused by megalocytiviruses in marine and freshwater ornamental fish were reported after 2005. Jeong et al. [30] revealed outbreaks of ISKNV in ten freshwater ornamental fish species (T. leeri, T. microlepis, C. lalia, Xiphophorus maculatus, X. helleri, Poecilia sphenops, Lebistes reticulatus, Astronotus ocellatus, Hyphessobrycon innesi, and Pterophyllum eimekei). The fish were sampled from wholesalers in Korea and importers from China and Singapore. All of the ornamental fish species tested were positive for iridovirus through two-step polymerase chain reaction (PCR). Paradise fish (Macropodus opercularis) imported from Indonesia [31], common platy, pearl gourami, zebrafish, swordtail, ram cichlid from major ornamental fish breeding states in peninsular Malaysia [32], platys $X$. maculatus from Australia [33], angelfish Pterophyllum altum imported from Colombia, platys $X$. maculatus 
of unknown origin [5], X. hellerii, X. maculatus, P. sphenops, T. trichopterus [4], Poecilia reticulata, T. leeri, Apistogramma ramirezi [3] from Southern Malaysia, zebrafish Danio rerio from a research facility in Spain [34], and three marine ornamental fish, Banggai cardinalfish P. kauderni [21], orbiculate batfish Platax orbicularis [35], and majestic angelfish Pomacanthus navarchus [2] have reported positive for megalocytiviruses. Other ornamental fish species from around the world that have been detected for megalocytiviruses infection since 1989 until 2019 are listed in Table-1 [1-5,15,16,20-22,25-27,30-32,34,36-41].

\section{Common Clinical Signs of Megalocytivirus in Ornamental Fish}

Megalocytivirus infection is known to cause non-specific clinical signs in infected ornamental fish, similar to clinical signs that are common for other diseases [13,42]. The most common external clinical signs observed due to Megalocytivirus infection (Table-2) $[1-5,13,15,16,21-23,25,28,31,38,42]$ and mortality $[5,13,35,42]$ have been reported in many studies. An unusual white fecal was produced by $P$. kauderni from California before the fish died [21]. Megalocytivirus-infected fish have been reported to be asymptomatic or apparently healthy $[1,3,4,30,34,35]$. The absence of specific clinical signs in ornamental fish has made it difficult for farmers to detect Megalocytivirus; therefore, Megalocytivirus-positive fish often exported overseas during the asymptomatic carrier stage $[3,4]$. Histological analysis is needed to observe the pathological signs caused by Megalocytivirus(Table-3)[1,4,16,21,26-28,31,38,43-47]. Megalocytivirus-infected fish are known to develop IBCs, which are mostly found in spleen, kidney, and liver $[16,22,23,29,37]$, considering the pathognomonics of infection with megalocytiviruses $[8,48]$. In addition, the histological results showed that the Megalocytivirus-like infection in juvenile angelfish $P$. scalare demonstrated massive necrosis and hemorrhage in the kidney and spleen and necrosis in the pancreas [26] and intestine of dwarf gourami C. lalia [24]. The production of basophilic hypertrophied cells $[13,21,27,29,38]$ is the most common symptom observed in Megalocytivirus-infected fish. Commonly affected sites include the submucosa and tunica propria of the intestine and stomach [16] instead of the spleen, liver, and kidney [38]. An experimental challenge of ISKNV in zebra fish (Danio rerio) showed erratic swimming patterns, lingering near the surface of the water, hemorrhages, and scale protrusion. Histological results found necrosis of tissue and enlarged cells in the kidney and spleen [49].

\section{Laboratory Diagnosis of Megalocytivirus Infection in Ornamental Fish}

Many studies have diagnosed Megalocytivirus infection using histopathology, cell culture, immunofluorescent antibody techniques, PCR, and more recently, loop-mediated isothermal amplification (LAMP) [50]. In ornamental fish, cell culture was initiated using imported freshwater dwarf gourami [24] and marine Banggai cardinalfish (P. kauderni) [21], but these efforts were unsuccessful due to the difficulty of isolation and propagation in cell cultures [51], lack of validated cell culture techniques [52], and the requirement for a longer duration [53]. The viral titrate and infectivity decreased on serial passages in many cell lines, although many common fish cell lines supported their growth [54,55]. Only few strains of megalocytiviruses could be diagnosed by cell culture, including RSIV in tilapia heart cell culture. RSIV can be cultured in tilapia heart cell culture using minimum essential medium, $10 \%$ fetal bovine serum, and $50 \mu \mathrm{g}$ gentamicin $/ \mathrm{ml}$, and incubating the cultures at $28^{\circ} \mathrm{C}$ [40]. Fortunately, in 2003, the Megalocytiviruslike viral particles isolated from dwarf gourami originated from Singapore and were found to be able to grow in BF-2 cells at $20^{\circ} \mathrm{C}$ in Scotland [27]. The cell culture lines that were used to detect Megalocytivirus are listed in Table-4 [16,46,54,56-67].

The first immunofluorescence test was used against RSIV using monoclonal antibodies in 1995 [68]; however, early or latent infection cannot be detected using this technique [53]. Among the advantages of this technique include the fact that it does not cross-react within megalocytiviruses (RSIV or SBIV) or ranaviruses (epizootic hematopoietic necrosis virus or GIV) [69]; it requires a short time (within $2 \mathrm{~h}$ ); and it provides precise results [50]. This assay is also suitable for the diagnosis of ISKNV [8]. Immunofluorescence has been used to detect ISKNV in experimentally infected zebrafish, $D$. rerio, in 2008. The ISKNV-infected hypertrophic cells were present in different organs of moribund zebrafish, including the spleen, kidney, liver, gill, esophagus, gut, and muscle, as detected using the viral protein VP23R, which is encoded by the ORF23R of ISKNV and specifically localized on the plasma membrane of the ISKNV-infected cells [49].

PCR is one of the most commonly used methods for detecting the viral DNA and MCP gene of Megalocytivirus [37]. There are different types of PCRs, but the most common method used to detect Megalocytivirus in ornamental fish are conventional and real-time PCRs. The conventional PCR detects the presence or absence of the DNA/RNA virus in infected fish. The most preferred method is real-time PCR, because it is more sensitive compared to conventional PCR [12], and specific DNA regions of species can be determined using specifically designed probes [70,71]. In contrast, conventional PCR is widely used in studies (Table-5) [1-5, 16,30-35,37,72].

Real-time PCR is more sensitive than conventional PCR for the detection of fish viruses. Rimmer et al. [52] demonstrated the sensitivity of real-time PCR for the detection of DGIV. The sensitivity was approximately 3-4 logs greater compared to the Office International des Epizooties reference PCR protocol. 
Table-1: Ornamental fish with known susceptibility to Megalocytiviruses around the world from year 1989 to 2019.

\begin{tabular}{|c|c|c|c|c|c|}
\hline Family & Species & Common name & Region of origin/country & Year & References \\
\hline Apogonidae & $\begin{array}{l}\text { Pterapogon } \\
\text { kauderni }\end{array}$ & $\begin{array}{l}\text { Banggai cardinalfish } \\
\text { (Marine) }\end{array}$ & $\begin{array}{l}\text { Banggai archipelago } \\
\text { through Bali or Singapore }\end{array}$ & $2003-2005$ & {$[21]$} \\
\hline Arapaimidae & Arapaima gigas & Arapaima & Brazil & 2015 & {$[2]$} \\
\hline \multirow[t]{9}{*}{ Cichlidae } & Astronotus ocellatus & Oscar & USA & Early $1990 s$ & {$[28]$} \\
\hline & & & Possibly South east Asia & 2004-2006 & {$[36]$} \\
\hline & & & $\begin{array}{l}\text { Malaysia/Sri Lanka/ } \\
\text { Singapore }\end{array}$ & 2013 & [37] \\
\hline & & & Thailand & 2016-2018 & [1] \\
\hline & Etroplus maculatus & Orange chromide & Singapore & 1989 & {$[22]$} \\
\hline & $\begin{array}{l}\text { Mikrogeophagus } \\
\text { ramirezi/ }\end{array}$ & Ram cichlid (blue ram) & $\begin{array}{l}\text { Malaysia/ Sri Lanka/ } \\
\text { Singapore }\end{array}$ & $2010-2012$ & [37] \\
\hline & Apistogramma & & Malaysia & Not specific & {$[32]$} \\
\hline & ramirezi & & Malaysia & 2017 & {$[3]$} \\
\hline & $\begin{array}{l}\text { Pterophyllum } \\
\text { scalare }\end{array}$ & Freshwater angelfish & Not specific & 1990 & {$[25,28]$} \\
\hline \multirow[t]{12}{*}{ Cichlidae } & $\begin{array}{l}\text { Pterophyllum } \\
\text { scalare }\end{array}$ & Freshwater angelfish & United Kingdom & 1997 & {$[25]$} \\
\hline & & & Singapore & $1992-2000$ & {$[27]$} \\
\hline & & & $\begin{array}{l}\text { Malaysia/Sri Lanka/ } \\
\text { Singapore }\end{array}$ & 2009 & [37] \\
\hline & & & Brazil & 2015 & {$[2]$} \\
\hline & & & Thailand & $2016-2018$ & [1] \\
\hline & Pterophyllum altum & $\begin{array}{l}\text { Altum angelfish, deep } \\
\text { angelfish, or Orinoco } \\
\text { angelfish }\end{array}$ & Columbia & 2014 & [5] \\
\hline & $\begin{array}{l}\text { Apistogramma } \\
\text { cacatuoides }\end{array}$ & Cockatoo dwarf cichlid & $\begin{array}{l}\text { Malaysia/Sri Lanka/ } \\
\text { Singapore }\end{array}$ & $2010-2012$ & [37] \\
\hline & Laetacara curviceps & Flag acara & $\begin{array}{l}\text { Malaysia/Sri Lanka/ } \\
\text { Singapore }\end{array}$ & 2010 & [37] \\
\hline & $\begin{array}{l}\text { Pelvicachromis } \\
\text { kribensis }\end{array}$ & Kribensis & $\begin{array}{l}\text { Malaysia/Sri Lanka/ } \\
\text { Singapore }\end{array}$ & 2012 & [37] \\
\hline & Tropheus duboisi & White spotted cichlid & $\begin{array}{l}\text { Malaysia/Sri Lanka/ } \\
\text { Singapore }\end{array}$ & 2012 & [37] \\
\hline & Cichlasoma sp. & - & Thailand & 2016-2018 & [1] \\
\hline & Symphysodon sp. & Discus & Thailand & 2016-2018 & [1] \\
\hline Characidae & $\begin{array}{l}\text { Paracheirodon } \\
\text { innesi }\end{array}$ & Neon tetra & Korea/Singapore/China & 2014 & [30] \\
\hline \multirow[t]{2}{*}{ Characidae } & Metynnis argenteus & Silver dollar & $\begin{array}{l}\text { Malaysia/Sri Lanka/ } \\
\text { Singapore }\end{array}$ & 2010 & [37] \\
\hline & Moenkhausia costae & Tetra fortune & Brazil & 2015 & {$[2]$} \\
\hline \multirow[t]{4}{*}{ Cyprinidae } & Carassius auratus & Gold fish & Brazil & 2015 & [2] \\
\hline & $\begin{array}{l}\text { Brachydanio } \\
\text { albolineatus }\end{array}$ & Pearl danio & Brazil & 2015 & [2] \\
\hline & Danio rerio & Zebrafish & Malaysia & Not specific & {$[32]$} \\
\hline & & & Spain & 2015 & [34] \\
\hline Cobitidae & $\begin{array}{l}\text { Misgurnus } \\
\text { anguillicaudatus }\end{array}$ & Pond loach & Brazil & 2015 & {$[2]$} \\
\hline Ephippidae & Platax orbicularis & $\begin{array}{l}\text { Orbiculate batfish } \\
\text { (Marine) }\end{array}$ & Indonesia & 2010 & {$[38]$} \\
\hline Helostomatidae & Helostoma & Kissing gourami & USA & Early 1990s & {$[28]$} \\
\hline & temminckii & & $\begin{array}{l}\text { Singapore, Sri Lanka, and } \\
\text { Thailand }\end{array}$ & 2011 & [35] \\
\hline Hemiodontidae & Hemiodus gracilis & Slender Hemiodus & Brazil & 2015 & {$[2]$} \\
\hline Loricariidae & $\begin{array}{l}\text { Hypostomus } \\
\text { plecostomus }\end{array}$ & Suckermouth catfish & Brazil & 2015 & {$[2]$} \\
\hline Labridae & Labroides dimidiatus & Doctor fish & South east Asia & 1995 & [39] \\
\hline Nothobranchiidae & $\begin{array}{l}\text { Fundulopanchax } \\
\text { gardneri }\end{array}$ & Blue lyretail & $\begin{array}{l}\text { Malaysia/Sri Lanka/ } \\
\text { Singapore }\end{array}$ & 2012 & [37] \\
\hline \multirow[t]{9}{*}{ Osphronemidae } & Betta splendens & Siamese fighting fish & Singapore & $1992-2000$ & [27] \\
\hline & & & Thailand & $2016-2018$ & {$[1]$} \\
\hline & $\begin{array}{l}\text { Colisa lalia/ } \\
\text { Trichogaster lalius }\end{array}$ & Dwarf gourami & Singapore & 1988 & [35] \\
\hline & & & USA & Early 1990s & {$[28]$} \\
\hline & & & Singapore & $1992-2000$ & [27] \\
\hline & & & Malaysia via Singapore & 2000 & {$[16]$} \\
\hline & & & South east Asia & 2004 & {$[20]$} \\
\hline & & & Singapore & 2004 & [30] \\
\hline & & & & & (Contd.. \\
\hline
\end{tabular}


Table-1: (Continued)

\begin{tabular}{|c|c|c|c|c|c|}
\hline Family & Species & Common name & Region of origin/country & Year & References \\
\hline & & & Indonesia and Thailand & 2011 & [35] \\
\hline & $\begin{array}{l}\text { Colisa labiosa/ } \\
\text { Trichogaster labiosa }\end{array}$ & Thick lipped gourami & Asia & 2006 & {$[19,20]$} \\
\hline & & & Thailand & 2011 & {$[35]$} \\
\hline & $\begin{array}{l}\text { Trichogaster } \\
\text { trichopterus/ } \\
\text { Trichopodus } \\
\text { trichopterus }\end{array}$ & $\begin{array}{l}\text { Three spot gourami/ } \\
\text { Blue or Gold gourami }\end{array}$ & USA & 1992 & {$[28,40]$} \\
\hline \multirow[t]{18}{*}{ Osphronemidae } & $\begin{array}{l}\text { Trichogaster } \\
\text { trichopterus/ } \\
\text { Trichopodus } \\
\text { trichopterus }\end{array}$ & $\begin{array}{l}\text { Three spot gourami/ } \\
\text { blue or gold gourami }\end{array}$ & $\begin{array}{l}\text { Indonesia, Singapore and } \\
\text { Thailand }\end{array}$ & 2011 & {$[35]$} \\
\hline & & & Brazil & 2015 & {$[2]$} \\
\hline & & & Malaysia & 2016 & {$[4]$} \\
\hline & Trichogaster leerii & Pearl gourami & USA & Early 1990 s & {$[28]$} \\
\hline & & & Singapore & $1992-2000$ & [27] \\
\hline & & & South east Asia & 2003 & [20] \\
\hline & & & Singapore & 2004 & {$[30]$} \\
\hline & & & Indonesia & 2011 & [35] \\
\hline & & & Brazil & 2015 & {$[2]$} \\
\hline & & & Malaysia & 2017 & {$[3]$} \\
\hline & & & Malaysia & Not specific & {$[32]$} \\
\hline & & & Israel & Not specific & {$[26]$} \\
\hline & $\begin{array}{l}\text { Trichogaster } \\
\text { microlepis }\end{array}$ & $\begin{array}{l}\text { Moonlight/silver } \\
\text { gourami }\end{array}$ & Singapore & 2004 & {$[30]$} \\
\hline & & & Brazil & 2015 & {$[2]$} \\
\hline & & & Malaysia & 2017 & [3] \\
\hline & & & Malaysia & Not specific & {$[32]$} \\
\hline & & & Israel & Not specific & {$[26]$} \\
\hline & $\begin{array}{l}\text { Trichogaster } \\
\text { microlepis }\end{array}$ & $\begin{array}{l}\text { Moonlight/silver } \\
\text { gourami }\end{array}$ & Singapore & 2004 & [30] \\
\hline \multirow[t]{2}{*}{ Osphronemidae } & $\begin{array}{l}\text { Macropodus } \\
\text { opercularis }\end{array}$ & Round tail paradise fish & Indonesia & $\begin{array}{l}2006 \text { and } \\
2008\end{array}$ & {$[31]$} \\
\hline & & & Brazil & 2015 & {$[2]$} \\
\hline \multirow[t]{12}{*}{ Poeciliidae } & $\begin{array}{l}\text { Aplocheilichthys } \\
\text { normani }\end{array}$ & $\begin{array}{l}\text { Norman's (African) } \\
\text { lampeye }\end{array}$ & Indonesia via Singapore & 1998 & [16] \\
\hline & Poecilia latipinna & Sailfin molly & $\begin{array}{l}\text { Malaysia/Sri Lanka/ } \\
\text { Singapore }\end{array}$ & 2012 & {$[37]$} \\
\hline & & & Thailand & 2016-2018 & {$[1]$} \\
\hline & & & Israel & Not specific & {$[26]$} \\
\hline & Xiphophorus hellerii & Swordtail & $\begin{array}{l}\text { Malaysia/Sri Lanka/ } \\
\text { Singapore }\end{array}$ & 2012 & [37] \\
\hline & & & Malaysia & 2016 & [4] \\
\hline & & & Thailand & 2016-2018 & {$[1]$} \\
\hline & & & Israel & Not specific & {$[26]$} \\
\hline & & & Malaysia & Not specific & [32] \\
\hline & $\begin{array}{l}\text { Xiphophorus } \\
\text { maculatus }\end{array}$ & Southern platy fish & $\begin{array}{l}\text { Malaysia/Sri Lanka/ } \\
\text { Singapore }\end{array}$ & 2012 & [37] \\
\hline & & & Not specific & 2014 & {$[5]$} \\
\hline & & & Brazil & 2015 & [2] \\
\hline \multirow[t]{12}{*}{ Poeciliidae } & $\begin{array}{l}\text { Xiphophorus } \\
\text { maculatus }\end{array}$ & Southern platy fish & Malaysia & $\begin{array}{l}2016 \text { and } \\
2017\end{array}$ & {$[3,15]$} \\
\hline & & & Thailand & $2016-2018$ & {$[1]$} \\
\hline & & & Israel & Not specific & {$[26]$} \\
\hline & & & Malaysia & Not specific & [32] \\
\hline & Poecilia reticulata & Guppy & South east Asia & 1995 & [41] \\
\hline & & & Korea/Singapore/China & 2014 & {$[30]$} \\
\hline & & & Brazil & 2015 & {$[2]$} \\
\hline & & & Thailand & 2016-2018 & {$[1]$} \\
\hline & & & Malaysia & 2017 & [3] \\
\hline & Poecilia sphenops & $\begin{array}{l}\text { Molly (or sphenops } \\
\text { molly) }\end{array}$ & Korea/Singapore/China & 2014 & [30] \\
\hline & & & Malaysia & 2016 & {$[4]$} \\
\hline & $\begin{array}{l}\text { Xiphophorus } \\
\text { variatus }\end{array}$ & Variable platy & Thailand & 2016-2018 & [1] \\
\hline Pomacanthidae & $\begin{array}{l}\text { Pomacanthus } \\
\text { navarchus }\end{array}$ & $\begin{array}{l}\text { Blue girdled angelfish/ } \\
\text { Majestic angelfish } \\
\text { (Marine) }\end{array}$ & Brazil & 2015 & {$[2]$} \\
\hline
\end{tabular}


Real-time PCR was used to analyze the mRNA level of ISKNV replicated in zebrafish [49]. In 2020, a new assay was discovered for the detection and genotyping of Megalocytivirus instead of DNA hybridization, which is known as peptide nucleic acid (PNA)-based real-time PCR assay in Korea [73]. It has more suitable hybridization traits that allow for a difference in the melting temperature, even by a single nucleotide mismatch, and discrimination of the genotypes of Megalocytivirus in a single simple assay [73]. Four PNA probes labeled with the respective fluorescence at their $3^{\prime}$ ends were designed as reporter molecules. The study was tested in rock bream (Oplegnathus fasciatus). The result for this new method was similar to the sequencing analysis of Megalocytivirus-infected fish and artificial samples (Figure-1).

LAMP assay is another method used to detect megalocytiviruses [74]. Basically, the LAMP assay

Table-2: The common external clinical signs of Megalocytivirus infection observed in ornamental fish.

\begin{tabular}{lc}
\hline External clinical signs & References \\
\hline Lethargy & {$[2,13,21,31,38]$} \\
Skin lesion & {$[38]$} \\
Abnormal swimming & {$[1,2,15,25,42]$} \\
pattern in the water & {$[2,5,15,21]$} \\
Loss of appetite & {$[1,3,15,16,21,22,42]$} \\
Pale or darkening body & {$[4,13,25,28]$} \\
coloration & {$[2,42]$} \\
Distended body & {$[4,16,22,25]$} \\
Ulceration & {$[1,15,21,23,28]$} \\
Pale gills anemia & {$[28]$} \\
Hemorrhages &
\end{tabular}

Table-3: The pathological findings of Megalocytivirus in affected fish.

\begin{tabular}{lc}
\hline Pathological signs & References \\
\hline Hypertrophic cells & {$[26,27]$} \\
Splenomegaly (enlargement of the & {$[1,16,31,38]$} \\
spleen) & {$[1,4,38]$} \\
Hepatomegaly (enlargement of liver) & {$[16,21,28]$} \\
Necrosis & {$[43-46]$} \\
Congestion & {$[47]$} \\
Heterochromatin of infected cell &
\end{tabular}

uses four primers to identify six different sequences of the target DNA [69,75]. Compared to PCR [76], LAMP is a simple, rapid (within an hour) $[50,77,78]$, specific, and cost-effective [50] nucleic acid amplification method that can be performed at temperatures between $60^{\circ} \mathrm{C}$ and $65^{\circ} \mathrm{C}[79,80]$. LAMP utilizes self-sustained sequence replication and can synthesize a large amount of DNA [76]. LAMP assay has been tested to detect megalocytiviruses in infected fish, including guppies, gourami, angelfish, swordtail fish, and platy [81]. This assay has been developed for TRBIV [78], RSIV [82], and ISKNV [83]. LAMP assay is very sensitive, as it can detect as little as ten copies of the megalocytiviral DNA target $[78,82,83]$. Subramaniam et al. [32] used acridine orange to improve the visual quality of the LAMP assay for ISKNV.

\section{Risk factors}

Temperature

High water temperatures had been shown to enhance the multiplication of Megalocytivirus [12,13,60,84]. Yanong and Waltzek [13] reported that Megalocytivirus could survive at temperatures ranging from $20^{\circ} \mathrm{C}$ to $32^{\circ} \mathrm{C}$. A review report from the Australian Department of Agriculture [6] stated that the relationship of infectivity of Megalocytivirus is inversely proportional to the temperature and time [6]. ISKNV can remain infective even when isolated and kept under $-70^{\circ} \mathrm{C}$ for $>8$ months and $40^{\circ} \mathrm{C}$ for $30 \mathrm{~min}$, but the virus was inactivated when it was isolated and kept under $50^{\circ} \mathrm{C}$ for $30 \mathrm{~min}$ [6]. This will give the optimum temperature for the virus to remain active throughout the year and could be one of the factors that lead to disease outbreak $[13,85]$. Limited studies have been conducted to evaluate the effect of temperature on Megalocytivirus in ornamental fish specifically, but some studies have been conducted on ISKNV in food fish; generally. ISKNV is one of the most isolated Megalocytivirus strains in ornamental fish $[6,13]$.

For example, in 2002, in China, the effect of temperature on the pathogenicity of ISKNV infection was conducted [86] in mandarin fish (Siniperca chuatsi). The fish was injected intraperitoneally with isolated

Table-4: The cell culture of Megalocytivirus strain in fish.

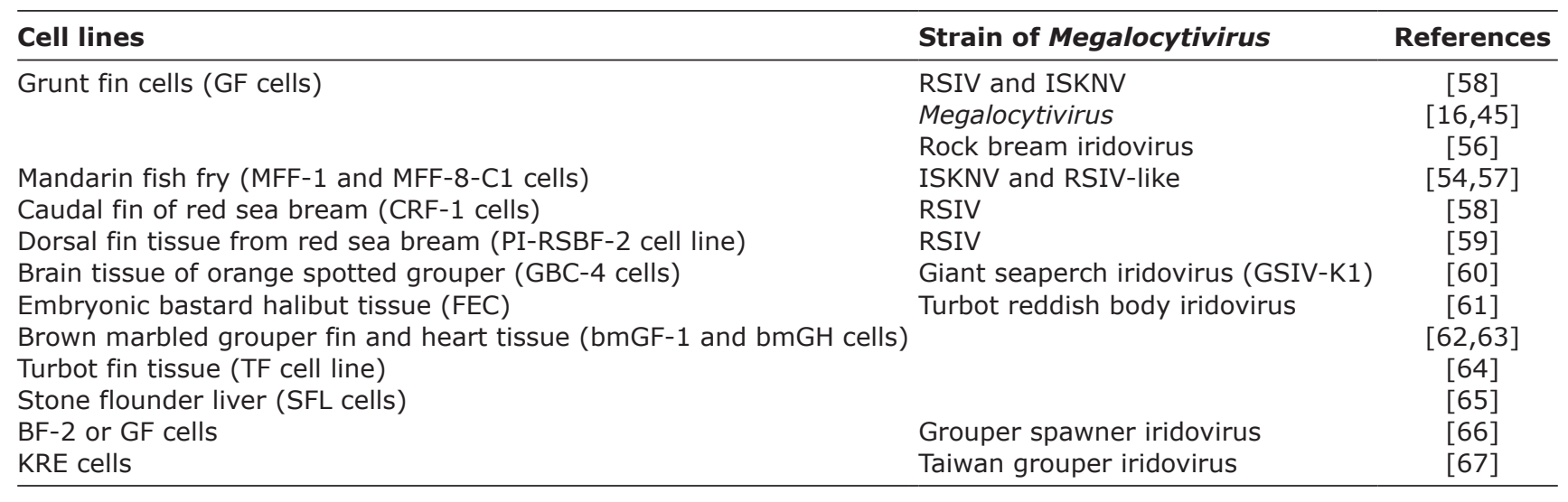


Table-5: Polymerase chain reaction assays used to detect Megalocytivirus in ornamental fish.

\begin{tabular}{|c|c|c|c|}
\hline Species & Common name & Assay type & References \\
\hline Aplocheilichthys normani & African lampeye & Single step & {$[16]$} \\
\hline Lebistes reticulatus & Guppies & Nested & {$[3,30]$} \\
\hline Poecilia sphenops & Molly & Nested & {$[4,30]$} \\
\hline Xiphophorus hellerii & Swordtail & Nested & {$[4,30]$} \\
\hline Trichogaster leeri & Pearl gourami & Nested & {$[3,30]$} \\
\hline Macropodus opercularis & Paradise fish & Nested & {$[2,31]$} \\
\hline Danio rerio & Zebra fish & Single step & {$[32,34]$} \\
\hline Pterophyllum altum & Angelfish & Single step & [5] \\
\hline \multirow[t]{2}{*}{ Colisa lalia } & Dwarf gourami & Single step & {$[16]$} \\
\hline & & Nested & {$[30]$} \\
\hline Hyphessobrycon innesi & Neon tetras & Nested & {$[30]$} \\
\hline Pterophyllum eimekei & Angelfish & Nested & \\
\hline Trichogaster microlepis & Silver gourami & Nested & \\
\hline \multirow[t]{5}{*}{ Xiphophorus maculatus } & Platy & Real-time PCR and nested & {$[1,33]$} \\
\hline & & qPCR and nested & {$[35]$} \\
\hline & & Nested & {$[2,4,30,37]$} \\
\hline & & Single step & [5] \\
\hline & & qPCR & {$[72]$} \\
\hline \multirow[t]{3}{*}{ Astronotus ocellatus } & Oscars & Real-time PCR and nested & [1] \\
\hline & & Nested & {$[30,37]$} \\
\hline & & qPCR & [72] \\
\hline \multirow[t]{3}{*}{ Mikrogeophagus ramirezi } & Ram cichlid & Nested & {$[3]$} \\
\hline & & Single step & [32] \\
\hline & & qPCR & [72] \\
\hline \multirow[t]{4}{*}{ Poecilia latipinna } & Sailfin molly & Real-time PCR and nested & {$[1]$} \\
\hline & & qPCR and nested & [35] \\
\hline & & Nested & [37] \\
\hline & & qPCR & {$[72]$} \\
\hline \multirow[t]{2}{*}{ Trichopodus trichopterus } & Gold gourami & Nested & {$[2,4]$} \\
\hline & & Real-time PCR and nested & [1] \\
\hline Helostoma temminckii & kissing gourami & qPCR & {$[72]$} \\
\hline Mikrogeophagus altispinosus & Bolivian ram & qPCR & \\
\hline Sphaerichthys sp & Chocolate gourami & qPCR & \\
\hline Species undefine & Discus & qPCR & \\
\hline Species undefine & Archerfish & qPCR & \\
\hline Carassius auratus & Goldfish & Nested & {$[2]$} \\
\hline Moenkhausia costae & Tetra fortune & Nested & \\
\hline Brachydanio albolineatus & Pearl danio & Nested & \\
\hline Misgurnus anguillicaudatus & Pond loach & Nested & \\
\hline Hypostomus plecostomus & Suckermouth catfish & Nested & \\
\hline Hemiodopsis gracilis & Slender hemiodus & Nested & \\
\hline Pomacanthus narvachus & Blue girdled angelfish & Nested & \\
\hline
\end{tabular}

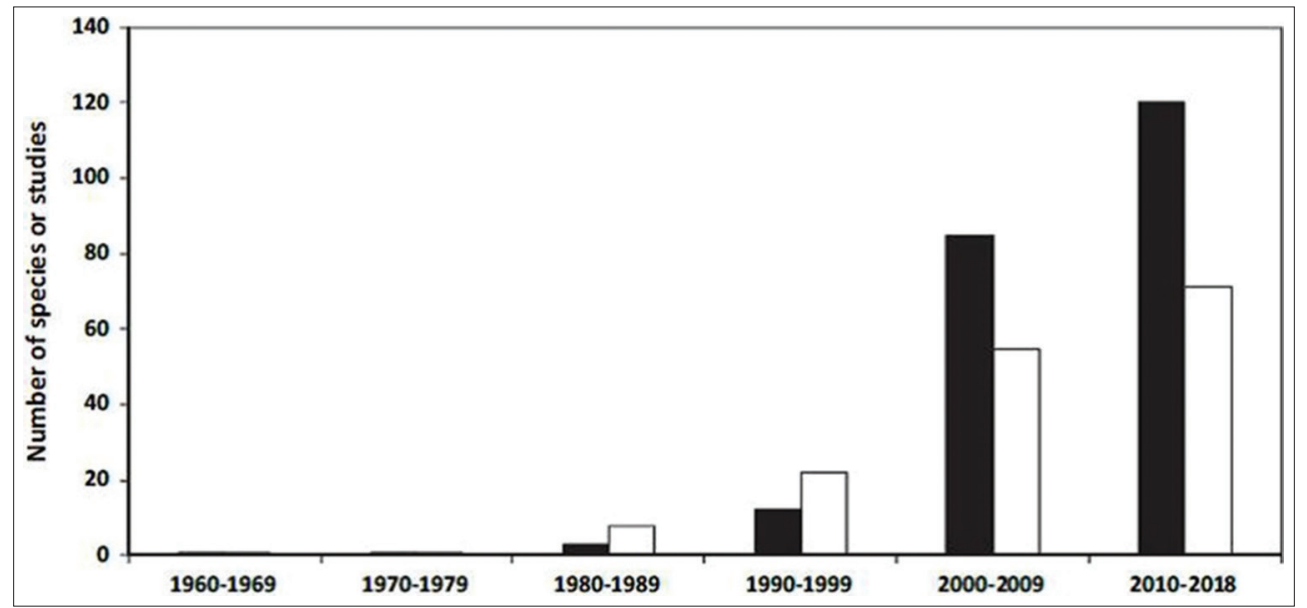

Figure-1: The results of genotype and quantitative using peptide nucleic acid probe in different diseased fish between 2012 and 2018 in Korea [73].

ISKNV. The result showed that total mortality occurred at $25^{\circ} \mathrm{C}$ and $34^{\circ} \mathrm{C}$, and the natural outbreaks of ISKNV in mandarin fish occurred at $20-32^{\circ} \mathrm{C}$. In another study in the same region, two-step PCR showed the percentage of ISKNV-like viruses detected in different seasons $(22.1 \%$ winter, $27.8 \%$ summer, $34.0 \%$ autumn, 
and $17.0 \%$ spring) and proved that water temperature is a key condition for ISKNV outbreaks [16]. In other regions, such as Malaysia and Indonesia, Megalocytivirus have been observed in water temperatures ranging from $28^{\circ} \mathrm{C}$ to $32^{\circ} \mathrm{C}$ annually [85], with the highest mortality occurring at $27^{\circ} \mathrm{C}$ [87].

\section{Transportation}

Transportation and translocation of ornamental fish could be the cause of the spread of Megalocytivirus [1,31]. Importation is one of the potential vectors of infection [41,86]. In South Korea, paradise fish $M$. opercularis imported from Indonesia was detected with Megalocytivirus [31]. In Thailand, a study was conducted on the translocation of Megalocytivirus contributing to its spread, and the result showed that the virus could spread by movement of the fries [1]. The transmission of Megalocytivirus in ornamental fish based on findings of the previous studies include horizontal transmission through contaminated water, cohabitation with infected fish, ingestion of infected excreta, and cannibalism $[6,20]$. So, far, no vertical transmission of Megalocytivirus has been reported until now.

\section{Life stages}

The life stages of fish have been reported as one of the risk factors for Megalocytivirus infection. Early detection of Megalocytivirus in fish has been detected at the juvenile stage. Anderson et al. [24] reported that juvenile to young adult dwarf gouramis were infected with Megalocytivirus. Juvenile cichlids (freshwater angelfish in the United Kingdom and orange chromide cichlids from Canada) also have been infected by Megalocytivirus [22,25]. These results indicate that the juvenile stage is more susceptible to infection of this virus in ornamental fish.

\section{Translocation}

Translocation of megalocytiviruses through transmission from infected ornamental fish to food fish also has been studied. Experimental transmission trials were undertaken to test the hypothesis that the outbreak of Murray cod (Maccullochella peelii peelii) fingerlings in Australis could have arisen through the introduction of a virus with ornamental gouramis imported from the Southeast Asia. The study showed that $90 \%$ mortality was induced in Murray cod fingerlings by cohabitation with dwarf gouramis, C. lalia [20]. Approximately $125-130 \mathrm{~nm}$ icosahedral virions were observed in lesions by histopathological analysis, and the DNA sequencing confirmed 99.9$100 \%$ homology between the MCP and ATPase nucleotide sequences of DGIV and ISKNV, as revealed by PCR [20]. These findings confirm that Murray cod is highly susceptible to a Megalocytivirus present in ornamental fish imported from Southeast Asia.

Moreover, a study conducted in South Korea on translocation of genus Megalocytivirus (pearl gourami iridovirus [PGIV]-SP) from freshwater ornamental fish, pearl gourami T. leeri, has shown that it can infect marine fish rock bream, $O$. fasciatus. The virus was isolated from infected pearl gourami and was injected intraperitoneally to the rock bream. The result showed $100 \%$ mortality of rock bream after 2 weeks of IP injection. The infection of PGIV-SP isolated from pearl gourami was confirmed by PCR assay [88]. This result proves that megalocytiviruses can be translocated from freshwater into marine habitats, where it can establish a new infection pathway if the virus is released into the natural environment.

In 2019, sixty ornamental fishes were collected from different areas of northern, central, and western Thailand. All were tested by PCR analysis. The result showed that the ornamental fishes were infected by Megalocytivirus. The translocation of the virus was analyzed using Chi-square test statistics, which proved that the translocation of Megalocytivirus from an unknown or Megalocytivirus-positive origin was related to disease occurrence [1].

\section{Prevention and Control Measures}

Vaccine development is important to minimize the infection of megalocytiviruses [89] and to increase the survival rate of fish. To date, vaccine development in aquaculture has focused on food fish only. Moreover, no vaccines have been developed for megalocytiviruses infection in ornamental fish. Due to the small size of the ornamental fish species, it is difficult to produce and administer vaccines to them without causing stress or side effects. There are various methods of fish vaccination, such as trough injection (intramuscular and intraperitoneal) [90], immersion, and oral $[90,91]$. Ornamental fish are mostly small in size compared to food fish, so the best vaccination for ornamental fish would be through immersion or the oral method.

Oral vaccination can be applied by mixing the vaccine with the feed $[89,92]$. Two techniques of oral vaccination that has been used for fish include bio-encapsulation and micro-encapsulation [89], but the most suitable and easiest method to use for ornamental fish is bio-encapsulation. Micro-encapsulation is used for sensitive antigens. The bio-encapsulation technique uses life feed, such as Artemia nauplii, rotifers, and copepods incubated in a vaccine suspension, which was then fed to the fish [92]. This method can be applied at the early stage of the fish life cycle (the juvenile stage) [93], as it can prevent early infection of megalocytiviruses in ornamental fish. The advantage of the oral vaccination is that it can be used easily in a large scale of small fish without stressing ornamental fish, and it can also lower the labor cost of vaccination development [93].

In addition, immersion vaccinations also can be used for ornamental fish. The immersion method includes bath and dip techniques [92]. As for the 
immersion method, the fish is normally submerged in water containing the diluted vaccine. The skin and gill absorb the suspended antigens from the vaccine. At that point, the fish would be protected from the live pathogens due to the activation of specialized cells that are present in the skin and gill epithelium, such as antibody-secreting cells [93]. The dip technique is more suitable for ornamental fish compared to the bath technique due to the fact that the technique uses a high concentration of vaccine solution and the fish are immersed in a very short time, approximately $30 \mathrm{~s}$. However, for the bath technique, the fish are immersed approximately 1 to several hours in a low concentration of vaccine solution [92]. Ornamental fish farmers are able to use the immersion technique, as this method can be used for a large-scale vaccination of a high number of ornamental fish, and it is suitable for all sizes of ornamental fish, reduces the labor cost for vaccination implementation, and finally, it can reduce stress [93] on the ornamental fish.

In ornamental fish in China, zebrafish were used to study the infection of ISKNV. The vaccine was administered by IP injection to the zebrafish. The results showed that recombinant zebrafish interferon 1 was used to protect zebrafish from infection by ISKNV after $6 \mathrm{~h}$ of injection; however, after $24 \mathrm{~h}$ of injection, the result was not significant enough to provide protection for zebrafish against ISKNV [94]. Studies on the pathogenic mechanisms of megalocytiviruses in ornamental fish must be done in the future to increase scientific knowledge of the ornamental fish immune system and the pathogenic and virulence mechanisms so that vaccines can be developed for ornamental fish infected megalocytiviruses.

In contrast, for aquacultured fish, the earliest vaccine was developed to prevent RSIV infection (another strain of Megalocytivirus) in Japan [95]. The commercialized injectable vaccine using formalin-inactivated RSIV showed that the survival of red seabream increased $19.2 \%$ in a field test [95]. This vaccine has been tested in vitro in other fish species, including yellow tail (Seriola quinqueradiata; 7\% mortality), amberjack (Seriola dumerili; 5\% mortality), kelp grouper (Epinephelus moara; 0\% mortality), and striped jack (Pseudocaranx dentex; 42\% mortality) in Japan, and glycogen storage disease type IV in humpback grouper Cromileptes altivelis from Bali Island, Indonesia, showed 0\% mortality $[96,97]$. Zhang et al. [98] constructed a vaccine against Megalocytivirus using the genes of rock bream iridovirus isolate 1 from China. The result showed that pCN86, a plasmid that expresses an 86-residue viral protein, is an effective DNA vaccine that may be used in aquaculture diseases. Furthermore, P247 and P523, the Megalocytivirus immunogens, were selected for use in the DNA vaccine (pCN247 and pCN523). An immune analysis showed that the vaccines induced the production of specific serum antibodies, causing the generation of cytotoxic immune cells and specific memory immune cells that responded to secondary antigen stimulation and upregulated the expression of genes involved in innate and adaptive immunity [99]. In Korea, Oh et al. [100] tested the RSIV vaccine in rock bream $O$. fasciatus at a low rearing temperature $\left(\leq 18^{\circ} \mathrm{C}\right)$ and showed that the infection was not expressed as a disease.

Good husbandry and biosecurity measures [11,89] could decrease the chances of Megalocytivirus infection as follows. Producers should quarantine any new fish in a separate building or area before the introduction of new fish in the pond, follow appropriate biosecurity protocols, separate incoming fish groups based on origin, use separate equipment, separate unhealthy fish from healthy fish, and disinfect water sources prior use [15]. In addition, farmers must improve their disease monitoring effort, and greater action can be taken by authorities to prevent the disease from spreading [11].

Viral diseases can be controlled by eradication [101] using chemical substances. Essentially, eradication is used to eliminate the disease from a defined geographical area [102]. The principal of eradication is to ensure that the prevalence of a disease is reduced to zero, with or without the use of intervention measures, and that there is total cessation of disease transmission in the defined geographical area [101]. As recent as 2019, in Australia, a study was conducted to evaluate the effect of disinfectants on inactivating ISKNV [101] in ornamental fish. The result showed that the protocols to disinfect ISKNV included using soiling conditions by heating at $65^{\circ} \mathrm{C}$ for $20 \mathrm{~min}$; immersed in $1000 \mathrm{ppm}$ sodium hypochlorite solution at a $\mathrm{pH} 3$ or $\mathrm{pH} 11$ for $30 \mathrm{~min}$ for $\mathrm{pH}$ treatment $(0.1 \mathrm{M}$ sodium hydroxide $(\mathrm{NaOH})$ or 11.65 $\mathrm{M}$ hydrochloric acid $(\mathrm{HCl})$ was added to ISKNV to adjust the $\mathrm{pH}$ level using digital $\mathrm{pH}$ meter and after 30 min at the desired $\mathrm{pH}, \mathrm{NaOH}$ or $\mathrm{HCl}$ was added to adjust the $\mathrm{pH}$ to 7.3 ); and soaking in 1\% Virkon ${ }^{\mathrm{TM}}$ or $650 \mathrm{ppm}$ benzalkonium chloride for $10 \mathrm{~min}$ for chemical treatments by buffer exchange (a regenerated cellulose 30,000 molecular weight cut-off membrane centrifuge device was prepared by pre-rinsing the membrane with ultrapure water (Amicon Ultra-15 Ultracel, Merck Millipore). Then, the buffer exchange device was loaded with the treated challenge inoculum and centrifuged at $4000 \mathrm{~g}$ for $5 \mathrm{~min}$ at $4{ }^{\circ} \mathrm{C}$ ) [101]. The quantitative PCR (qPCR) was assessed for the quantity of ISKNV DNA before and after the disinfection method [101]. The disinfection methods and practical application must be explored in future studies, because different regions around the world have different geographical characteristics; thus, different approaches have to be implemented according to regional factors. A cost-effective measure must be developed to lower the cost of farm maintenance so that early outbreaks of megalocytiviruses in the farm can be prevented. 


\section{Conclusion}

This is the first review of occurrence of Megalocytivirus in ornamental fish since its first detection in 1989. Megalocytivirus causes non-specific clinical signs, persists as a carrier in some species, and causes mortalities in other species. The disease is of great concern, as it can cause high mortalities in ornamental fish farming, thus leading to severe economic losses in the aquaculture industry. The disease could be caused by many factors, such as temperature, transportation, and life stages. The future of this industry should lead toward the development of vaccines and other treatment methods for Megalocytivirus as an approach to decrease infection cases around the world.

\section{Authors' Contributions}

CACJ contributed to the original draft and conception of the specific review. SCZ contributed to the review, editing, and supported in supervision. CACJ and SCZ worked on the final approval of the version to be published. All authors read and approved the final manuscript.

\section{Acknowledgments}

The support of the Faculty of Fisheries and Food Science, University Malaysia Terengganu to the first two authors is gratefully acknowledged. The authors were supported by Universiti Malaysia Terengganu's Human Resource Talent Development Fund, vot. no. 64943 for the industrial attachment at the ornamental fish industry.

\section{Competing Interests}

The authors declare that they have no competing interests.

\section{Publisher's Note}

Veterinary World remains neutral with regard to jurisdictional claims in published institutional affiliation.

\section{References}

1. Baoprasertkul, P. and Kaenchan, N. (2019) Distribution and detection of Megalocytivirus in ornamental fish in Thailand. J. Fish. Environ., 43(1): 11-24.

2. Lucca-Maganha, S.R., Cardoso, P.H.M., de Carvalho Balian, S., de Almeida-Queiroz, S.R., Fernandes, A.M. and de Sousa, R.L.M. (2018) Molecular detection and phylogenetic analysis of Megalocytivirus in Brazilian ornamental fish. Arch. Virol., 163(8): 1-7.

3. Zainathan, S.C., Balaraman, D., Ambalavanan, L., Moorthy, P.K., Palakrishnan, S.K. and Ariff, N. (2019) Molecular screening of infectious spleen and kidney necrosis virus in four species of Malaysian farmed ornamental fish. Malays. Appl. Biol., 48(1): 131-138.

4. Zainathan, S.C., Johan, C.A.C., Subramaniam, N., Ahmad, A.A., Halim, N.I.A., Norizan, N. and Ariff, N. (2017) Detection and molecular characterization of Megalocytivirus strain ISKNV in freshwater ornamental fish from Southern Malaysia. Aquac. Aquar. Conserv. Legis., 10(5): 1098-1109.

5. Jung-Schroers, V., Adamek, M., Wohlsein, P., Wolter, J.,
Wedekind, H. and Steinhagen, D. (2016) First outbreak of an infection with infectious spleen and kidney necrosis virus (ISKNV) in ornamental fish in Germany. Dis. Aquat. Organ., 119(3): 239-244.

6. Department of Agriculture. (2014) Importation of Freshwater Ornamental Fish: Review of Biosecurity Risks Associated with Gourami Iridovirus and Related Virusesfinal Import Risk Analysis Report. Commonwealth of Australia, Department of Agriculture, India.

7. Hyatt, A.D., Gould, A.R., Zupanovic, Z., Cunningham, A.A., Hengst-Berger, S., Whittington, R.J., Kattenbelt, J. and Coupar, B.E.H. (2000) Comparative studies of piscine and amphibian iridoviruses. Arch. Virol., 145(2): 310-331.

8. Kurita, J. and Nakajima, K. (2012) Megalocytiviruses. Viruses, 4(4): 521-538.

9. Chinchar, V.G., Hick, P., Ince, I.A., Jancovich, J.K., Marschang, R., Qin, Q., Subramaniam, K., Waltzek, T.B., Whittington, R., Williams, T., Zhang, Q. and ICTV Report Consortium. (2017) ICTV virus taxonomy profile: Iridoviridae. J. Gen. Virol., 98(5): 890-891.

10. King, A.M. (2011) Virus Taxonomy: Classification and Nomenclature of Viruses: Ninth Report of the International Committee on Taxonomy of Viruses. Elsevier, Amsterdam, Netherlands.

11. Ivan, K.M.C., Andrew, M.S. and Yin, S.L. (2019) The significance of major viral and bacterial diseases in Malaysian aquaculture industry. Pertanika J. Trop. Agric. Sci., 42(3): 1023-1047.

12. Wang, C.S. and Wen, C.M. (2017) Megalocytiviruses. In: Liu, D., editor. Molecular Detection of Animal Viral Pathogens. CRS Press, Boca Raton, Florida. p825-833.

13. Yanong, R.P.E. and Waltzek, T.B. (2010) Megalocytivirus Infections in Fish, with Emphasis on Ornamental Species. University of Florida EDIS, Florida

14. Whittington, R., Becker, J. and Dennis, M. (2010) Iridovirus infections in finfish-critical review with emphasis on ranaviruses. J. Fish Dis., 33(2): 95-122.

15. Song, J.Y., Kitamura, S.I., Jung, S.J., Miyadai, T., Tanaka, S. and Fukuda, Y. (2008) Genetic variation and geographic distribution of megalocytiviruses. J. Microbiol., 46(1): 29-33.

16. Sudthongkong, C., Miyata, M. and Miyazaki, T. (2002a) Iridovirus disease in two ornamental tropical freshwater fishes: African lampeye and dwarf gourami. Dis. Aquat. Organ., 48(3): 163-173.

17. Do, J.W., Cha, S.J., Kim, J.S., An, E.J., Park, M.S., Kim, J.W., Kim, Y.C., Park, M.A. and Park, J.W. (2005) Sequence variation in the gene encoding the major capsid protein of Korean fish iridoviruses. Arch. Virol., 150(2): 351-359.

18. Caipang, C.M.A., Takano, T., Hirono, I. and Aoki, T. (2006) Genetic vaccines protect red seabream, Pagrus major, upon challenge with red seabream Iridovirus (RSIV). Fish Shellfish Immunol., 21(2): 130-138.

19. Go, J., Lancaster, M., Deece, K., Dhungyel, O. and Whittington, R. (2006) The molecular epidemiology of Iridovirus in Murray cod (Maccullochella peelii peelii) and dwarf gourami (Colisa lalia) from distant biogeographical regions suggests a link between trade in ornamental fish and emerging iridoviral diseases. Mol. Cell. Probes, 20(3-4): 212-222.

20. Go, J. and Whittington, R. (2006) Experimental transmission and virulence of a Megalocytivirus (Family Iridoviridae) of dwarf gourami (Colisa lalia) from Asia in Murray cod (Maccullochella peelii peelii) in Australia. Aquaculture, 258(1-4): 140-149.

21. Weber, E.S., Waltzek, T.B., Young, D.A., Twitchell, E.L., Gates, A.E., Vagelli, A., Risatti, G.R., Hedrick, R.P. and Frasca, S. Jr. (2009) Systemic Iridovirus infection in the banggai Cardinal fish (Pterapogon kauderni Koumans 1933). J. Vet. Diagn. Invest., 21(3): 306-320.

22. Armstrong, R. and Ferguson, H. (1989) Systemic viral disease of the chromide cichlid Etroplus maculatus. Dis. 
Aquat. Organ., 7: 155-157.

23. Schuh, J.C.L. and Shirley, I.G. (1990) Viral hematopoietic necrosis in an angelfish (Pterophyllum scalare). J. Zoo Wildl. Med., 21(1): 95-98.

24. Anderson, I.G., Prior, H.C., Rodwell, B.J. and Harris, G.O. (1993) Iridovirus-like virions in imported dwarf gourami (Colisa lalia) with systemic amoebiasis. Aust. Vet. J., 70(2): 66-67.

25. Rodger, H.D., Kobs, M., Macartney, A. and Frerichs, G.N. (1997) Systemic Iridovirus infection in freshwater angelfish, Pterophyllum scalare (Lichtenstein). J. Fish Dis., 20(1): 69-72.

26. Paperna, I., Vilenkin, M. and de Matos, A.P.A. (2001) Iridovirus infections in farm-reared tropical ornamental fish. Dis. Aquat. Organ., 48(1): 17-25.

27. Gibson-Kueh, S., Netto, P., Ngoh-Lim, G.H., Chang, S.F., Ho, L.L., Qin, Q.W., Chua, H.C., Ng, M.L. and Ferguson, H.W. (2003) The pathology of systemic iridoviral disease in fish. J. Comp. Pathol., 129(2-3): 111-119.

28. Petty, B.D. and Fraser, W.A. (2005) Viruses of pet fish. Vet. Clin. North Am. Exot. Anim. Pract., 8(1): 67-84.

29. Hick, P., Becker, J. and Whittington, R. (2016) Iridoviruses of fish. In: Frederick, K. and Marcos, G.G., editors. Aquaculture Virology. Academic Press, London, United Kingdom. p127-152.

30. Jeong, J.B., Kim, H.Y., Jun, L.J., Lyu, J.H., Park, N.G., Kim, J.K. and Jeong, H.D. (2008) Outbreaks and risks of infectious spleen and kidney necrosis virus disease in freshwater ornamental fishes. Dis. Aquat. Organ., 78(3): 209-215.

31. Kim, W., Oh, M., Kim, J., Kim, D., Jeon, C. and Kim, J. (2010) Detection of Megalocytivirus from imported tropical ornamental fish, paradise fish Macropodus opercularis. Dis. Aquat. Organ., 90(3): 235-239.

32. Subramaniam, K., Shariff, M., Omar, A.R., Hair-Bejo, M. and Ong, B.L. (2014) Detection and molecular characterization of infectious spleen and kidney necrosis virus from major ornamental fish breeding states in peninsular Malaysia. J. Fish Dis., 37(7): 609-618.

33. Mohr, P.G., Moody, N.J.G., Williams, L.M., Hoad, J., Cummins, D.M., Davies, K.R. and Crane, M.S. (2015) Molecular confirmation of infectious spleen and kidney necrosis virus (ISKNV) in farmed and imported ornamental fish in Australia. Dis. Aquat. Organ., 116(2): 103-110.

34. Bermudez, R., Losada, A.P., Azevedo, A.M., GuerraVarela, J., Perez Fernandez, D., Sanchez, L., Padros, F., Nowak, B. and Quiroga, M.I. (2018) First description of a natural infection with spleen and kidney necrosis virus in zebrafish. J. Fish Dis., 41(8): 1283-94.

35. Rimmer, A.E., Becker, J.A., Tweedie, A., Lintermans, M., Landos, M., Stephens, F. and Whittington, R.J. (2015) Detection of dwarf gourami Iridovirus (infectious spleen and kidney necrosis virus) in populations of ornamental fish prior to and after importation into Australia, with the first evidence of infection in domestically farmed platy (Xiphophorus maculatus). Prev. Vet. Med., 122(1-2): 181-194.

36. Whittington, R., Tweedie, A., Dennis, M., Becker, J. and Landos, M. (2009) Aquatic Animal Health Subprogram: Optimisation of PCR Tests for Diagnosis of Megalocytivirus (Gourami Iridovirus) and Cyprinid herpesvirus 2 (Goldfish Herpesvirus). University of Sydney, Australia.

37. Nolan, D., Stephens, F., Crockford, M., Jones, J.B. and Snow, M. (2015) Detection and characterization of viruses of the genus Megalocytivirus in ornamental fish imported into an Australian border quarantine premises: An emerging risk to national biosecurity. J. Fish Dis., 38(2): 187-195.

38. Sriwanayos, P., Francis-Floyd, R., Stidworthy, M.F., Petty, B.D., Kelley, K. and Waltzek, T.B. (2013) Megalocytivirus infection in orbiculate batfish Platax orbicularis. Dis. Aquat. Organ., 105(1): 1-8.

39. Raja, K., Aanand, P., Padmavathy, S. and Sampathkumar, J.S.
(2019) Present and future market trends of Indian ornamental fish sector. Int. J. Fish Aquat. Stud., 7(2): 6-15.

40. Fraser, W.A., Keefe, T.J. and Bolon, B. (1993) Isolation of an iridovirus from farm-raised gouramis (Trichogaster trichopterus) with fatal disease. J. Vet. Diagn. Invest., 5(2): 250-253.

41. Hedrick, R.P. and Mcdowell, T.S. (1995) Properties of iridoviruses from ornamental fish. BMC Vet. Res., 26(5-6): 423-427.

42. Cardoso, P.H.M., Moreno, A.M., Moreno, L.Z., Oliveira, C.H., Baroni, F.A., Maganha, S.R.L., Sousa, R.L.M. and Balian, S.C. (2019) Infectious diseases in aquarium ornamental pet fish. Braz. J. Vet. Res. Anim. Sci., 56(2): e151697.

43. He, J.G., Wang, S.P., Zeng, K., Huang, Z.J. and Chan, S.M. (2000) Systemic disease caused by an Iridovirus-like agent in cultured mandarin fish, Siniperca chuatsi (Basilewsky), in China. J. Fish Dis., 23(3): 219-222.

44. Jung, S.J. and Oh, M.J. (2000) Iridovirus-like infection associated with high mortalities of striped beak perch, Oplegnathus fasciatus (Temminck et Schlegel), in Southern coastal areas of the Korean peninsula. J. Fish Dis., 23(3): 223-226.

45. Murwantoko, M., Handayani, C.R. and Pratiwi, R. (2009) Cloning and sequence analysis of capsid protein gene of Iridovirus Indonesian isolates. Indones. J. Biotechnol., 14(1): 1117-1123.

46. Sudthongkong, C., Miyata, M. and Miyazaki, T. (2002b) Viral DNA sequences of genes encoding the ATPase and the major capsid protein of tropical Iridovirus isolates which are pathogenic to fishes in Japan, South China Sea and Southeast Asian countries. Arch. Virol., 147(11): 2089-2109.

47. Chao, C.B., Chen, C.Y., Lai, Y.Y., Lin, C.S. and Huang, H.T. (2004) Histological, ultrastructural, and in situ hybridization study on enlarged cells in grouper Epinephelus hybrids infected by grouper Iridovirus in Taiwan (TGIV). Dis. Aquat. Organ., 58(2-3): 127-142.

48. Chinchar, V.G., Hyatt, A.D., Miyazaki, T. and Williams, T. (2009) Family Iridoviridae: Poor viral relations no longer. In: Van Etten, J.L., editor. Lesser Known Large DsDNA Viruses. Springer-Verlag, Berlin. p123-170.

49. Xu, X., Zhang, L., Weng, S., Huang, Z., Lu, J., Lan, D., Zhong, X., Yu, X., Xu, A., He, J. (2008) A zebrafish (Danio rerio) model of infectious spleen and kidney necrosis virus (ISKNV) infection. Virology, 376(1): 1-12.

50. Go, J. (2015) Megalocytiviruses of Freshwater Ornamental Fish and Pathogenicity in Marine and Euryhaline Species, Doctoral Dissertation. The University of Sydney, Sydney, Australia.

51. Gias, E., Johnston, C., Keeling, S., Spence, R.P. and McDonald, W.L. (2011) Development of real-time PCR assays for detection of megalocytiviruses in imported ornamental fish. J. Fish Dis., 34(8): 609-618.

52. Rimmer, A.E., Becker, J.A., Tweedie, A. and Whittington, R.J. (2012) Development of a quantitative polymerase chain reaction (qPCR) assay for the detection of dwarf gourami Iridovirus (DGIV) and other megalocytiviruses and comparison with the Office International des epizooties (OIE) reference PCR protocol. Aquaculture, 3580-359: 155-163.

53. Nakajima, K., Maeno, Y., Fukudome, M., Fukuda, Y., Tanaka, S., Matsuoka, S. and Sorimachi, M. (1995) Immunofluorescence test for the rapid diagnosis of red sea bream Iridovirus infection using monoclonal antibody. Fish Pathol., 30(2): 115-119.

54. Dong, C., Shuang, F., Weng, S. and He, J. (2013) Cloning of a new fibroblast cell line from an early primary culture from mandarin fish (Siniperca chuatsi) fry for efficient proliferation of megalocytiviruses. Cytotechnology, 66(6): 883-890.

55. Nakajima, K. and Sorimachi, M. (1994) Biological and physico-chemical properties of the Iridovirus isolated from cultured red sea bream, Pagrus major. Fish Pathol., 29(1): 
29-33.

56. Jun, L.J., Jeong, J.B., Kim, J.H., Nam, J.H., Shin, K.W., Kim, J.K., Kang, J.C. and Jeong, H.D. (2009) Influence of temperature shifts on the onset and development of red sea bream iridoviral disease in rock bream Oplegnathus fasciatus. Dis. Aquat. Organ., 84(3): 201-208.

57. Dong, C.F., Weng, S.P., Shi, X.J., Xu, X.P., Shi, N. and He, J.G. (2008) Development of a mandarin fish Siniperca chuatsi fry cell line suitable for the study of infectious spleen and kidney necrosis virus (ISKNV). Virus Res., 135(2): 273-281.

58. Imajoh, M., Ikawa, T. and Oshima, S.I. (2007) Characterization of a new fibroblast cell line from a tail fin of red sea bream, Pagrus major, and phylogenetic relationships of a recent RSIV isolate in Japan. Virus Res., 126(1-2): 45-52.

59. Ku, C.C., Lu, C.H. and Wang, C.S. (2010) Establishment and characterization of a fibroblast cell line derived from the dorsal fin of red sea bream, Pagrus major (Temminck and Schlegel). J. Fish Dis., 33(3): 187-195.

60. Wen, C.M., Lee, C.W., Wang, C.S., Cheng, Y.H. and Huang, H.Y. (2008) Development of two cell lines from Epinephelus coioides brain tissue for characterization of Betanodavirus and Megalocytivirus infectivity and propagation. Aquaculture, 278(1-4): 14-21.

61. Chen, S.L., Ren, G.C., Sha, Z.X. and Shi, C.Y. (2004) Establishment of a continuous embryonic cell line from Japanese flounder Paralichthys olivaceus for virus isolation. Dis. Aquat. Organ., 60(3): 241-246.

62. Wei, Y.B., Fan, T.J., Jiang, G.J., Sun, A., Xu, X.H. and Wang, J. (2009) Establishment of a novel fin cell line from brown-marbled grouper, Epinephelus fuscoguttatus (Forsskal), and evaluation of its viral susceptibility. Aquac. Res., 40(13): 1523-1531.

63. Wei, Y.B., Fan, T.J., Jiang, G.J., Xu, X.H. and Sun, A. (2010) A novel heart-cell line from brown marbled grouper Epinephelus fuscoguttatus and its susceptibility to Iridovirus. J. Fish Biol., 76(5): 1149-1158.

64. Fan, T.J., Ren, B.X., Geng, X.F., Yu, Q.T. and Wang, L.Y. (2010) Establishment of a turbot fin cell line and its susceptibility to turbot reddish body Iridovirus. Cytotechnology, 62(3): 217-223.

65. Xu, J., Bao, Z. and Han, X. (2011) A novel cell line from liver of stone flounder, Kareius bicoloratus, and its susceptibility to different iridoviruses. J. World Aquac. Soc., 42(1): 73-81.

66. Jung, S., Miyazaki, T., Miyata, M., Danayadol, Y. and Tanaka, S. (1997) Pathogenicity of Iridovirus from Japan and Thailand for the red sea bream Pagrus major in Japan, and histopathology of experimentally infected fish. Fish. Sci., 63(5): 735-740.

67. Chou, H., Hsu, C. and Peng, T. (1998) Isolation and characterization of a pathogenic Iridovirus from cultured grouper (Epinephelus sp.) in Taiwan. Fish Pathol., 33(4): 201-206.

68. Nakajima, K. and Sorimachi, M. (1995) Production of monoclonal antibodies against red sea bream Iridovirus. Fish Pathol., 30(1): 47-52.

69. Subramaniam, K., Shariff, M., Omar, A.R. and HairBejo, M. (2012) Megalocytivirus infection in fish. Rev. Aquac., 4(4): 221-233.

70. Caipang, C.M., Hirono, I. and Aoki, T. (2003) Development of a real-time PCR assay for the detection and quantification of red seabream Iridovirus (RSIV). Fish Pathol., 38(1): 1-7.

71. Pallister, J., Gould, A., Harrison, D., Hyatt, A., Jancovich, J. and Heine, H. (2007) Development of real-time PCR assays for the detection and differentiation of Australian and European ranaviruses. J. Fish Dis., 30(7): 427-438.

72. Hood, Y., Sadler, J., Poldy, J., Starkey, C.S. and Robinson, A.P. (2019) Biosecurity system reforms and the development of a risk-based surveillance and pathway analysis system for ornamental fish imported into Australia.
Prev. Vet. Med., 167: 159-168.

73. Eun, S.L., Miyoung, C., Eun, Y.M., Sung, H.J. and Kwang, I.K. (2020) Novel peptide nucleic acid-based real-time PCR assay for detection and genotyping of Megalocytivirus. Aquaculture, 518: 734818.

74. Notomi, T., Okayama, H., Masubuchi, H., Yonekawa, T., Watanabe, K., Amino, N. and Hase, T. (2000) Loopmediated isothermal amplification of DNA. Nucleic Acids Res., 28(12): E63.

75. Williams, T. (1996) The iridoviruses. Adv. Virus Res., 46: 354-412.

76. Mori, Y. and Notomi, T. (2009) Loop-mediated isothermal amplification (LAMP): A rapid, accurate, and cost-effective diagnostic method for infectious diseases. J. Infect. Chemother., 15(2): 62-69.

77. Tomita, N., Mori, Y., Kanda, H. and Notomi, T. (2008) Loop-mediated isothermal amplification (LAMP) of gene sequences and simple visual detection of products. Nat. Protoc., 3(5): 877-882.

78. Zhang, Q.L., Shi, C.Y., Huang, J., Jia, K.T., Chen, X.H. and Liu, H. (2009) Rapid diagnosis of turbot reddish body Iridovirus in turbot using the loop-mediated isothermal amplification method. J. Virol. Methods, 158(1-2): 18-23.

79. Mori, Y., Nagamine, K., Tomita, N. and Notomi, T. (2001) Detection of loop-mediated isothermal amplification reaction by turbidity derived from magnesium pyrophosphate formation. Biochem. Biophys. Res. Commun., 289(1): 150-154.

80. Nagamine, K., Watanabe, K., Ohtsuka, K., Hase, T. and Notomi, T. (2001) Loop-mediated isothermal amplification reaction using a non-denatured template. Clin. Chem., 47(9): 1742-1743.

81. Ahmed, N. (2015) Development of LAMP Assay for Detection of Megalocytivirus in Ornamental Finfish, (Master's Thesis). Central Institute of Fisheries Education, Mumbai, India.

82. Caipang, C.M.A., Haraguchi, I., Ohira, T., Hirono, I. and Aoki, T. (2004) Rapid detection of a fish Iridovirus using loop-mediated isothermal amplification (LAMP). J. Virol. Methods, 121(2): 155-161.

83. Ding, W.C., Chen, J., Shi, Y.H., Lu, X.J. and Li, M.Y. (2010) Rapid and sensitive detection of infectious spleen and kidney necrosis virus by loop-mediated isothermal amplification combined with a lateral flow dipstick. Arch. Virol., 155(3): 385-389.

84. Jung, M.H., Jung, S.J., Vinay, T.N., Nikapitiya, C., Kim, J.O., Lee, J.H., Lee, J. and Oh, M.J. (2015) Effects of water temperature on mortality in Megalocytivirus-infected rock bream Oplegnathus fasciatus (Temminck et Schlegel) and development of protective immunity. J. Fish Dis., 38(8): 729-737.

85. Jiran, V.A. and Ransangan, J. (2013) Effect of water temperature on susceptibility of culture marine fish species to vibriosis. Int. J. Res. Pure Appl. Microbiol., 3(3): 48-52.

86. He, J.G., Zeng, K., Weng, S.P. and Chan, S.M. (2002) Experimental transmission, pathogenicity and physical-chemical properties of infectious spleen and kidney necrosis virus (ISKNV). Aquaculture, 204(1-2): 11-24.

87. Putra, B.S., Hick, P.M., Hall, E., Whittington, R.J., Khairul, R., Evarianti, Nurbariah. and Becker, J.A. (2020) Prevalence of infectious spleen and kidney necrosis virus (ISKNV), nervous necrosis virus (NNV) and ectoparasites in juvenile Epinephelus spp. farmed in Aceh, Indonesia. Pathogens, 9(7): 578.

88. Jeong, J., Cho, H., Jun, L., Hong, S., Chung, J. and Jeong, H. (2008) Transmission of Iridovirus from freshwater ornamental fish (pearl gourami) to marine (rock bream). Dis. Aquat. Organ., 82(1): 27-36.

89. Assefa, A. and Abunna, F. (2018) Maintenance of fish health in aquaculture: Review of epidemiological approaches for prevention and control of infectious disease of fish. Vet. Med. Int., 82(1): 27-36. 
90. Harikrishnan, R., Balasundaram, C. and Heo, M.S. (2011) Fish health aspects in grouper aquaculture. Aquaculture, 320(1-2): 1-21.

91. Mutoloki, S., Munang'andu, H.M. and Evensen, Ø. (2015) Oral vaccination of fish-antigen preparations, uptake, and immune induction. Front. Immunol., 6: 519.

92. Yanong, R.P. (2008) Use of Vaccines in Finfish Aquaculture. $1^{\text {st }}$ ed. University of Florida Press, Florida, USA.

93. Dhar, A.K. and Allnutt, F.C.T. (2011) Challenges and opportunities in developing oral vaccines against viral diseases of fish. J. Mar. Sci. Res. Dev., S1: 003.

94. Li, Z., Xu, X., Huang, L., Wu, J., Lu, Q., Xiang, Z., Liao, J., Weng, S., Yu, X. and He, J. (2010) Administration of recombinant IFN1 protects zebrafish (Danio rerio) from ISKNV infection. Fish Shellfish Immunol., 29(3): 399-406.

95. Nakajima, K., Maeno, Y., Honda, A., Yokoyama, K., Tooriyama, T. and Manabe, S. (1999) Effectiveness of a vaccine against red sea bream iridoviral disease in a field trial test. Dis. Aquat. Organ., 36(1): 73-75.

96. Mahardika, K., Haryanti H., Muzaki, A and Miyazaki, A.T. (2008) Histopathological and ultrastructural features of enlarged cells of humpback grouper Cromileptes altivelis challenged with Megalocytivirus (Family Iridoviridae) after vaccination. Dis. Aquat. Organ., 79(2): 163-168.
97. Nakajima, K., Ito, T., Kurita, J., Kawakami, H., Itano, H., Fukuda, Y., Aoi, Y., Tooriyama, T. and Manabe, S. (2002) Effectiveness of a vaccine against red sea bream iridoviral disease in various cultured marine fish under laboratory conditions. Fish Pathol., 37(2): 90-91.

98. Zhang, M., Hu, Y.H., Xiao, Z.Z., Sun, Y. and Sun, L. (2012) Construction and analysis of experimental DNA vaccines against Megalocytivirus. Fish Shellfish Immunol., 33(5): 1192-1198.

99. Zhang, J., Zhang, B.C. and Sun, L. (2015) P247 and P523: Two in vivo-expressed Megalocytivirus proteins that induce protective immunity and are essential to viral infection. PLoS One, 10(3): 1-21.

100. Oh, S.Y., Oh, M.J. and Nishizawa, T. (2014) Potential for a live red seabream Iridovirus (RSIV) vaccine in rockbream Oplegnathus fasciatus at a low rearing temperature. Vaccine, 32(2): 363-368.

101. Cahya, F., Paul, M.H. and Joy, A.B. (2019) Stability of infectious spleen and kidney Necrosis virus and susceptibility to physical and chemical disinfectants. Aquaculture, 506: 104-111.

102. Cockburn, T.A. (1961) Eradication of infectious diseases-control is an unending operation-after eradication, no further effort is required. Science, 133(3458): 1050-1058.

\section{$* * * * * * * *$}

